\title{
ResearchOnline@JCU
}

This is the Accepted Version of a paper published in the Journal of Environmental Education

Whitehouse, Hilary (2018) Questions of ecopedagogy in tropical oceanScapes in the age of coral ecocide: an autoethnographic description. Journal of Environmental Education, 49 (2). pp. 142-151.

http://dx.doi.org/10.1080/00958964.2017.1417226

(C) 2017. This manuscript version is made available under the CC-BY-NC-ND 4.0 license http://creativecommons.org/licenses/by-nc-nd/4.0/

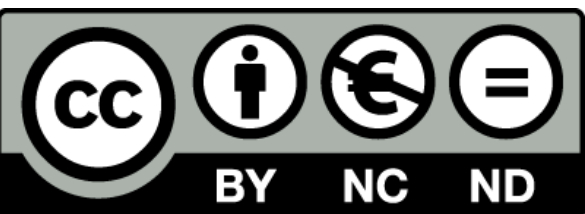




\section{Questions of ecopedagogy in tropical oeanscapes in the age of coral ecocide: An autoethnographic description}

Hilary Whitehouse, College of Arts, Society and Education, James Cook University, Cairns, Australia Final Draft submitted for publication December 2017

\section{ABSTRACT}

KEYWORDS

ecopedagogy; coral reefs; ecocide; reef education; oceanscapes; snorkeling; autoethnography, Great Barrier Reef

Trust your heart if the seas catch fire, live by love though the stars walk backwards. ee cummings (1950) dive for dreams

It is, I promise, worse than you think. (David Wallace-Wells, 2017)

\section{Introduction}

My formulation and discussion of ecopedagogy as/in ocean-sea scapes, scoped through repeat immersive experiences of coral reefs and educational studies, begins with an authoethnographic account of a series of personal stories of floating, snorkeling and traversing the coral ecologies offshore from the city of Cairns, in tropical northeastern Australia. These four serial encounters over the time-space of 2015 to 2017 (Dunkley, this issue) of an increasingly

desolated, even decidedly ecocidal, reef/water environment, emerges from the ecopedagogy of the ocean that I describe in the first half of this paper. I first went to the Great Barrier Reef (GBR) as part of my undergraduate education. I have memories of the smell of diesel fumes wafting over the back on the university's boats, of being sea sick, and of snorkeling on a shallow reef flat, rich with fish, and suddenly encountering a shark, and thinking that the shark looked absolutely perfect in its environment before I turned tail and swam hastily for the boat. I remember my peers laughing at me because I was frightened of a reef shark, who are generally harmless. My excuse was it was my very first real life, real time shark encounter, and the deeper, more reactive, elements of my brain were in play. Another memory of was of watching a large black manta ray flapping over a sandy hollow. This time I did not flee. Rather, I hung there in the water for some time feeling like a witness to a secret ritual. I also remember getting horribly sunburnt, as those were bikini days.

A number of years later, my $\mathrm{PhD}$ aimed at inquiring into the discourses disrupting the nature/culture binary in tropical Australian environments. I was philosophically searching for a more substantive and realistic comprehension of relational pedagogy. I interviewed a number of marine scientists who spoke freely to me about their liminal, underwater experiences (Davis and Whitehouse, 1997; Whitehouse, 2000). My first PhD student was Dr Carl Stepath, who completed a unique and comprehensive, mixed methods, study into the difference that immersive experiences in coral reefs have on high school and university student knowledge and attitudes (Stepath and Whitehouse, 2008; Stepath, 2015). Stepath (2015) showed conclusively taking adolescents to the reef and getting them into the water had statistically significant effects on their testable knowledge and positive attitudes towards coral reefs. As Carl's supervisor, I always wished he could have 'swum' his PhD thesis, I have never felt so safe and secure immersed in offshore environments than I felt being in the water with Carl. In his company giant barracudas passed by and I did not panic. In my explorations of finding a way past the western ontological obsession with binaries, I have written on Australia as a nature-culture (Whitehouse, 2011) and, with my colleagues, explored the ontological and educational formations of sea country (Whitehouse et al., 2014). My favourite children's book is Margaret Mahy's 1973 version of The man whose mother was a pirate. When the "little man" finally gets to the sea, taking his pirate mother in a wheelbarrow,

"he could only stare. He hadn't dreamed of the BIGNESS of the sea. He hadn't dreamed of the blueness of it. He hadn't thought it would roll like kettledrums, and swish itself on to the beach. He opened his mouth and the drift and the dream of it, the weave and the wave of it, the fume and foam of it never left him again".

\section{Sequential coral journeys - an autoethnography}

The first story: In the summer wet season of December 2015, I went to Flynn Reef in the Great Barrier Reef Marine Park (GBRMP) in the western Pacific Ocean off the North East coast of Australia with environmental education (EE) colleagues, Ruth Zee and Snowy Evans, on a field trip with a group of science and education students from James Cook University. As a university group we were accompanying a large group of ten and eleven year olds from a local state primary school along with their teachers, parents, and aides. Gunggandji, Djunbunji and Yirrganydji Aboriginal rangers from the Department of National Parks, Sport and Racing, Queensland Parks and Wildlife Service (QPWS) were on board the vessel as were marine biologists from Reef Magic Education (the boat provider). The intention was to develop our tertiary students' skills in offshore marine education (Whitehouse et al., 2017) working practically with young children on a real coral reef on what was a relatively pleasant day. The wind was moderate, the swell low and the water was incredibly warm. While our university students looked after the primary school children in the water, learning what immersive coral reef education really does entail, Ruth and I snorkeled further out over the reef flat.

At that time Flynn Reef was a glorious, vibrant, and extant coral garden. The corals were uniformly magnificent hues of blue, pink, violet, orange and yellow. I was fascinated to observe that day that every, single giant clam 
had an individual colour design as if to express their different clammy preferences and personalities. Clams take on algae to incorporate into their own tissues. There were clams who boldly fielded startling green with black designs, claims that preferred combinations of purple and pink, some decorated their lips with shocking yellow. Bobbing on the surface I lifted my mask and said to Ruth, "This is beyond sublime, is there a such a word for such magnificence in English?" The visual experience was quite beyond words. Such sublimity, I experienced as a mental state. Snorkeling is usually positioned as an embodied experience, which it is. But the mind is also at work underwater. Jay Griffiths (2015) writes that the "underwater mind" is a mind "that belongs" (p. x). That sense of belonging is truly profound.

Our earliest perceptions and both creatures and individual foetus are of gentle, thrilling waters. All mind began here: memory, perception, fear and desire. Ocean is full of wild mind. It melts the separation of mind and body and loosens the distinction between self and world ... Ocean dissolves the arbitrary dry idea of mankind's [sic] island mind ... You have a sense, underwater, of diffused mind, participation which doesn't deny or restrict individual mind but enhances it because no mind can believe itself dry-islanded down here. (Griffiths 2015, p. x)

The second story: In late January 2016, Ruth Zee and I went on a day trip to Moore Reef, another nearby in the GBRMP. As environmental educators living in Cairns, we took advantage of the opportunity to hop on a tour boat and snorkel an offshore reef as a day out. Moore Reef is heavily used as a tourism site. Coral reef tourism is one of the fastest growing sectors worldwide and snorkeling and diving tourism does have an effect on coral health (Lamb \& Willis 2011, Lamb et al. 2014). However, tourism on this northern section of the Great Barrier Reef is highly regulated compared with the rest of the world, so the Moore Reef 'natural' experience is still considered meaningful for its many visitors. Again, the weather was good, the swell low and the water extremely warm. While snorkeling through the lagoon, a younger Maori Wrasse, named Willy amused itself for several minutes by repeatedly charging and head butting me. Willy lives on the outer areas of the lagoon, the more famous and larger wrasse at Moore Reef is named Wally and Wally is endlessly photographed. Both Willy and Wally began their lives as females. Maori Wrasse change sex when males are needed. On this day, Willy bumped his nose straight into my mask and I looked into its shiny, unfathomable, fishy eye - a different eye to that of the dying wolf described by Leopold that Payne (2018) uses to highlight the 'face to face' moral encounter of ecopedagogy. Then Willy rolled his body over my legs and into the air. I laughed with the pleasure of it. "I can add being head butted by a large, blue fish to the list of my significant life experiences" (Tanner, 1980; Chawla, 1998) I told Ruth.

The boat operator gives locals a substantial discount so we booked an escorted tour to the reef drop off. The marine biologist, after explaining the direction of the current, let us float over the drop off and explained different creatures. The coral was a magnificent cascade of colour and shapes and there were dense schools of large and small fish. This time, I was entranced by a group squid who were conducting a conversation with each other, their skin fluorescing with ribbons of blue, quickly replaced by pink and orange and then turning back to blue, a kaleidoscope of moving colour. I had seen this phenomenon on television, however, techno/digitally mediated and designed, cerebral knowledge does not compare to the experience of witnessing colour-shifting squid in real life, in real time, immersed in a living reef. Colour (as we humans perceive it) on any reef indicates life, health, vibrancy, extant-ness and continuity through time.

The third story: On a Saturday in late April 2017, I took a group of senior academics from Australia and New Zealand on another reef trip, hosted by my former student and extraordinary marine educator, Marie Taylor. My colleagues, Elaine Sharplin and Ruth Zee, came too. In early April 2016, Ruth and Elaine had travelled to Fitzroy Island and returned with pictures of the bleached, white coral in the island's fringing reef. Then they had visited Moore Reef with the university group later in the same month. "Seeing is believing", said Elaine. We took our academic visitors to Moore Reef. The wind was up and the swell was choppy but we all hopped into the water nonetheless. "This is the first week the surface water temperature has dropped below 30 degrees" (Centigrade) the marine biologist informed us. We swam out to the lagoon. There was no overexcited Willy Wrasse lurking to head butt anyone; "He's disappeared", said Marie.

This shocking immersive experience contrasted significantly from the first two. Most of the staghorn corals in the lagoon were bleached; some a conglomeration of white skeletons with large sections others covered in brown algal slime. There were patches of fluorescing corals. Marie explained this was a bad sign. High water temperatures stress corals. First they fluoresce, and then they expel their zooxanthellae and turn bright white. At this white, 'bleached' stage corals are still alive but starving as they can only get about $5 \%$ of their energy needs though their own efforts - it is through the symbiosis with zooxanthellae that corals remain alive and flourishing. Mass coral bleaching is "primarily caused by prolonged exposure to thermal stress" (Reef 2050 Plan IEP, 2017). If water temperatures do not drop, the corals cannot recover their life - giving single celled algae and so they die of starvation. This is when the other algae, the brown algal slime, take over.

"What do you think?" said Marie to me as we bobbed up and down in the chop of the lagoon. "I am shocked", I said. The shock of seeing the desolation of the reef was like a body blow. I felt it all the way through my chest and gut. "If I wasn't wearing a rashie, I think my boobs would fall off from the shock", I admitted. "It's bad, isn't it?" said Marie.

Marie and two lovely marine biologists took the whole group to the drop off. The difference from the previous visit in January 2016 was hard to comprehend. There were fewer fish. There were no squid. The drop off wall was a conglomeration of white, brown, pale and highly fluorescing coral. I was looking and looking, rapidly trying to sort out my feelings. I knew I had to come up with something conclusive to say, this would be expected. I had to pronounce something other than the expletives that were running through my head. Back on board I said, "It's been a profound privilege to witness this bleaching". And I meant it.

Back in the staff room I announced to Snowy I was suffering reef grief. "I can't bear to think about it", she replied, "It's so difficult".

The fourth story: Marie arranged subsequent trips for James Cook University students and school students to Flynn Reef and Moore Reef in August and September 2017. We looked at the bleaching on these reefs and the small signs of recovery. However, my final story is about the reef trip JCU PhD student Matt Buttacavoli and I did to Moore Reef in late October 2017 to accompany the Cairns Reef Blitz team and Australia's Chief Scientist Alan Finkel. A group of very 
interested persons accompanied Professor Alan Finkel AO and his wife, Dr Elizabeth (Ella) Finkel AM, as they snorkeled the lagoon and the drop off. One reason we were there was to encourage these highly distinguished visitors to see the desolation through our eyes. There was very little recovery of corals in the lagoon. Most corals were dead and covered in algae. I was observing a group of green filefish hanging over a mass of white, staghorn coral in the lagoon when the Chief Scientist surfaced, raised his mask and spoke these words to me - "It's a wasteland", he declared.

On the ocean side of Moore Reef, the corals were looking much better. I recorded in my diary that, "Corals are trying to live. They are really, really trying to live". Corals that have greater access to cooler currents and flows recover better than the ones in the lagoon where the waters are "sticky" (as in the doldrums). Professor Finkel wrote to Marie thanking her for the 'eye-opening' experience. It was through snorkeling that he came to understand the co-existence of dead and thriving corals and therefore came to better understand the competing public reports on coral reef health. He said he had left Cairns significantly better informed than when he arrived. The purpose of the day had been achieved.

Finkel (2017) is the primary author of the Blueprint for the future report that argues for a whole of economy emissions reduction plan and "a nationally consistent approach to energy policy that recognises Australia's commitment in Paris to reduce emissions and governments' commitment to align efforts to meet this target with energy market frameworks". The Office of the Chief Scientist also funded the Role of energy storage in Australia's future energy mix report that examines "scientific, technological, economic and social aspects of the role that energy storage can play in Australia's transition to a low-carbon economy over the coming decade and beyond (ACOLA, 2017). However, the national and state politics concerning Australia's transition away from a carbon dense economy are complex, and such a transition is unlikely to happen quickly enough to save the majority of the hard corals that form the substrate of the national icon.

A rational approach to coral reef ecopedagogy and, by extension, marine/oceanscape ecopedagogy, must be openeyed and truthful with respect to anthropogenic global heating and its consequences. The reality is that when the surface seas are hot enough for long enough, nothing can protect coral reefs (Hughes et al. 2017). Corals that have the resilience to survive one or two bleaching events may not have the resilience to survive continuing, successive summers with above average water temperatures. System resilience is measurably and subjectively lost (Stedman, 2016) and then more bleaching occurs at a lower level of heat stress when the capacity (e.g. time and absence of stressors) is progressively diminished. The horrible fact, as pointed out by David Wells-Wallace (2017), is that, "more than half of the carbon humanity has exhaled into the atmosphere in its entire history has been emitted in just the past three decades; since the end of World War II, the figure is 85 percent [meaning] the story of the industrial world's kamikaze mission is also the story of a single lifetime"- my lifetime in fact.

The Reef 2050 Plan Independent Expert Panel (IEP), led by the former Chief Scientist, Professor Ian Chubb, has advised that a consequence of the sequential 2016 and 2017 bleaching events is that the diversity of surviving reefs "will be different from their historical state" (2017, p. 3). The IEP warns that "unrestrained" atmospheric and oceanic warming "will force the loss, degradation and change of coral reefs world-wide" (p.4). The tipping point is estimated at the level of a 1.2 degree $\mathrm{C}$ global average rise. (We have experienced an overall one-degree rise to date.) This ecological limit was widely reported in the Australian media (for example, Hannam, 2017a). It is most unlikely warming will be stabilized anywhere close to another 0.2 degree Celsius rise, and Australian domestic emissions are still climbing (Hannam, 2017b).

These successive reef trips during times of reef ecocide [see Krien, 2017; Kunnie, 2015] have been a profound pedagogical journey for me and for my colleagues and the students we accompany on these boat trips to different reef ecologies (Whitehouse et al. 2017). We have come to realize that death on (and of) reefs is not something should be avoided, no matter how heart wrenching. This is our Anthropocenic reality. This accumulation of reef encounters has developed our/my conception that educators cannot hide themselves or their students from these immeasurably sad realities. I am often asked whether it is wise to expose children and adolescents to bleached reefs. I always answer yes - for what is the alternative? To lie or to ignore realities or pretend things are otherwise? Experiencing changes, temporally and spatially, has unfolded a much deeper sense of understanding an integrated theoretical and practical ecopedagogy of and in reefscapes and oceanspace. I am more and more convinced, that despite the proliferation of shocking images of reef damage on the Internet and all the hand ringing reports, people have to get into the water to witness and then to truly understand. Corals are trying to live, to be alive and flourishing in their ancient, well-decided ways. However, how humans presently conduct their monoptic, economic, political and environmental business is not giving corals an even chance to live their lives.

\section{Traversing ecopedagogy and oceanscapes and coral ecocide}

The term 'eco' in ecopedagogy indicates the educational prospect of actively paying attention to the lives of others and to the aliveness of others, recognizing their living importance within normalized understandings of human enterprise. The ideal is to learn and teach with proper respect to the reality of our beautiful planet and with respect to the other's desire to live. As illustrated above in the four unfolding narratives that describe a coralscape scoping,

oceanscape ecopedagogy is deeply affective - mobile and sensory (Payne 2014); energetic and salty; as well as an act of a mind pushing across the air/water boundaries (Griffiths, 2015). While it becomes exceedingly difficult to talk and write about the ocean without mentioning the extreme pollution (carbon, plastic, heat, noise,

chemical), and extreme biodiversity loss (dead zones, ecological collapses), the oceans remain extraordinary. The focus in this account is the 'getting into' warm salt water as pedagogical experience and being able to engage cognitively and affectively with the profound sensory experience in witnessing what is present and what is absent, what is alive and what is dead, or diying.

Snorkeling is an old human activity, certainly in Australia, with its thousands of kilometres of coastal scapes. Aboriginal and Torres Strait Islander peoples have been 'snorkeling' Australia's reefs for thousands of years using hollow tubes of various materials. Snorkeling is a means for traversing the surface of the sea, for "moving" (see Rodrigues, this issue) in ocean water with the pleasure of breathing normally through a curved tube. Snorkeling is a highly immersive, 
relatively low technology experience of movement experiences in marine settings (cf SCUBA) and available for most people of different ages and abilities who are sufficiently comfortable in moving, fluid water to, simply, see through a mask, breathe through a snorkel and propel themselves gently with fins. For additional safety, a snorkeler (as a person who snorkels) can use a floatation jacket, a pool noodle, a flotation ring, and a wet suit. Even in warm waters it is advisable to cover up with a nylon bodysuit or rashii as this fabric deters jellyfish (including Chironex and the small and dangerous Irikanji species) from stinging a human body. It is also advisable to wear a nylon hood, as a sunburnt scalp is unpleasant and somewhat embarrassing.

Underwater, as Griffiths (2015, p. x) writes, "our heads are immersed, we are connected far more directly and immediately to everything else". The wonderfully named Tidal Tao: peace. love. snorkel tour

operator describes snorkeling on their website as the "opportunity to observe underwater life in a natural setting without the complicated equipment and training required for scuba diving". Snorkeling "appeals to all ages because of how little effort there is, and ... for most people, this is their first introduction to marine life and inevitably want more". Tidal Tao enthuses that, "snorkeling is something we should be promoting more of". As a simple and relatively cost effective means for accessing the ocean, snorkeling is "the perfect way to expose people of all ages, develop their interest and curiosity about our rich marine biodiversity" (Tidal Tao, 2017).

However - and at the pointy end of the Anthropocene, I am learning, there is always a 'however' - any discussion or practice of oceanscape ecopedagogy cannot escape the matter of ecocide. As exposed in my introductory authoethnography, what I was struggling with was not the lengthy administrative procedures, practical administrative duties and educational processes of getting myself, my students, and my colleagues out to the reef, though these institutional restrictions are increasingly part of the 'governance' of going to the reef (Whitehouse et al., 2017). What I was struggling with was the desolation of witnessing coral ecocide.

Bearing witness to the unprecedented crime of ecocide sweeping our planet is not accepting the carnage; it is lending another voice to testify on the behalf of the victims. And in doing so, it succeeds in making the difficult case for the worth of the human soul. (Kenn Orphan, 2014)

A witness (noun) is someone who has observed an event and has the authority to speak to that event. To witness (verb) is to experience, feel, and have practical/existential knowledge of an event gained from direct participation. Venturing offshore and into oceans, this direct participation is immersive. Humans with their heads in seawater lose their normal sense of air-hearing and the accustomed feel of gravity (Griffiths, 2015). What humans connect to is something more profound and elemental.As the osmotic pressure of the salt in our blood meets that of the salt in the water, our eyes open, our body connects, our sea-hearing kicks in. Revealed are the clicks of the manta shrimp, the rustling sound of bodies moving, of sands shifting, of water lapping and the odd fish rushing at you. What you see is dependent on water clarity and depth. But the thing is, you feel, hear, see, and move differently. Because you are there, and because you are in the salty water and feel keenly, you become openly responsive to the sea - light, warmth, viscosity, choppiness, smoothness -and what you feel and think is profoundly moving in sensory and emotional terms.

One archetypal witness of the twentieth century was journalist Wilfred Burchett, who on reflecting on "keeping both eyes and both ears open during my forty years' reporting" (usually of war) became more and more convinced of his "great faith in ordinary human beings and the sane and decent way they behave when they have the true facts of the case" (Burchett, 1981, p. x). Witnessing is an act of trust and respect. My colleagues, students and I became reluctant educational witnesses to the Anthropocene / Dromosphere (Payne, 2017). Despite working and learning as (and to be) science and environmental educators, and being highly informed about the science of global warming, we were completely taken aback that coral reef collapse of 2015-2017 happened on 'our watch'. Like almost everyone else, we were seduced into thinking that climate change catastrophes were a condition of the future, not of the right now, the present past, or passed. We suddenly had to come to see the shocking reality. We were forced into the hard realisation that the coral reefs we love, the local ones, right offshore from the beautiful city of Cairns may well become soupy algal "wasteland" before we are old.

The environmental journalist Greg Foyster (2016) who, in interrogating his own reactions to climate change, came to the conclusion that, "It's not the literal denial of [deniers] that will be a barrier in the future. That phase is over. It's the subtle, unspoken denial of people who fully accept the science, but deny the implications". This lapse is perfectly understandable. The emotional implications are almost too much to bear and in order to bear them, we must endlessly discuss our feelings, when we feel able, or not think of them at all. The professional implications for environmental educators are, that if we are going to continue to educate with authenticity (our desirable aim), then the timeliness, or not, of the antecedents and consequences of anthropogenic climate destabilization has to be front and centre of every ecopedagogical discussion we have, right now. The 'times' (and spaces) of reef ecocide, the surface and now deep ocean warming, the fluxes of El Nino and La Nina are intensifying 'accelerants' of the demise of the once impossibly numerous 'others' who live in the sea. The reefs along the Queensland coast, and in every other part of the world, have been in decline for decades. The acceleration of coral and ocean life ecocide is reaching levels of panic among the many who know, see and care (Hughes et al., 2017). How are environmental educators are going to properly deal with very rapid environmental change wherever we are in the world is an urgent question.

Wake up! You have to! You are in charge of one of the most beautiful underwater creations in the world, a vast turquoise structure made up of living corals, a section of the world that is essentially gills, and it can't breathe. (Anna Krien 2017, p. 115) 
Anna Krein (2017) called her Quarterly Essay on coral, coal and the national, political climate deadlock, The Long Goodbye. The title indicates Australians are going to be saying 'goodbye' to our national icon, the Great Barrier Reef. I am presently not certain that the 'goodbye' is going to take that long. For many reefs it may be quite a short goodbye.

\section{Honesty and oceanscape ecopedagogy in the Anthropocene/Dromosphere}

For whatever we lose (like a you or a me), it's always ourselves that we find in the sea. ee cummings (1956), maggie and milly and molly and may

We are from the sea. The sea is we. Almost 300 million people live within 30km of a coral reef (Lamb et al., 2014), and I am one of them. Established forms of thinking in environmental and marine education and our established research tropes are no longer so well fitting these immediate and distressing conditions. The Reef 2050 IEP (2017, p. 6) notes that communities along the Queensland coast "are learning about the phenomenon of mass bleaching and damage to the ecosystem together, with no long historical guide to assist in developing a response". In crafting an appropriate educational response, environmental educators can draw on many decades of pedagogical theorising and discussion. However, as Paul Virilio (2010, p, x) writes, "the time of an intellectual having an influence is over. Who has an influence? It is the climate".

Phillip Payne (2014, 2018 this issue), expands the idea of the Anthropocene to the Anthropocene/Dromosphere in recognition of the temporal acceleration of the planetary and geologically historical time-space conditions we now 'face' within a political economy of speed. Burk (2011) calls it "our headlong rush into the future-present". The cultural theorist, Paul Virilio (2010) drew on the Greek noun dromos (race track) from which he made the term dromology, defined as the science or logic of speed. Subsequently, the appellation Dromosphere has been applied as a means for recognizing the rapid acceleration of history and the concomitant acceleration of new forms of technologies that create dissimulation from reality (Nakagawa, 2018, this issue). Under this form of postmodern analysis, the destruction of coral reefs can be positioned as of as one of the 'accidents' of hyper-capitalism, in the sense that these theorised "accidents are unintentional byproducts inherent to the intentional narcissism of progress" (Rousselle, 2012). But is coral reef destruction really un-intentional?

Virilio (2010) concentrated much of his thinking and work on warfare, the havoc and destruction humans wreak on each other. Polly Higgins (who is a lawyer and international advocate, not a cultural theorist) deploys the term 'ecocide' to describe the material war waged by humans (historically and contemporarily) against the natural world. The term ecocide was first used by the biologist Arthur Galston in 1970 and literally translates as "killing our home" (Wijdekop, 2016). Higgins calls the lack of a legal duty of care towards ecosystems the "greatest injustice of our time". It is not a crime in Australia to cause extensive damage, destruction to or loss of ecosystems such as the Great Barrier Reef. Meaning, "dangerous industrial activity continues unabated and the knock-on impact of loss and damage remains unaddressed" (Higgins 2017a). Interestingly, the case for the Great Barrier Reef being a victim of ecocide was argued by the Global Alliance for the Rights of Nature in 2014. The case in whole can be viewed at http://therightsofnature.org/greatbarrier-reef-case-brisbane/

Ecocide is not unwitting, nor unintentional. Ecocide is deliberately driven by state policy and funding supporting corporate interests. Higgins (2017b) informs us that ecocide is a crime of recklessness. It is not a crime of consequence, as too much evidence has been established. Higgins (2017b) argues, that since the Paris Agreement, "we have a situation where the mens rea in ecocide crime is that of recklessness, i.e. disregarding available information and proceeding/or failing to prevent, regardless of knowledge" The nexus of recklessness between the corporate and the state is well established and neither corporations nor states "can declare lack of knowledge" (Higgins, 2017b) when it comes to mass bleaching of coral reefs. The scientific and educational effort put into reef studies over the last fifty years calls out the "intentional narcissism" of hyper-capitalism. As Krien (2017) argues, the considerable knowledge of reef ecology is ignored, dismissed, or only considered marginally within the political ecology of Australia.

Environmental educators have stood as pacifists and protestors against this intense and accelerating global extinction effort. But environmental and marine education has been paid little attention, or marginalized in Australian education discourses and practices over the last 20 years (Gough, 2017). Educators now have to consider the difficult task of having to educate in a time of rapid ecocide. What exactly does it mean to do coral reef education when the reefs are subject to continuing bleaching events, and when each successive event pushes extant reefs into a death spiral? Is there an ecopedagogy for a dying reef? My answer is yes, there is. Orphan (2014) writes that, "it is in grief that we find ourselves to be inseparable from each another".

If you don't like any of this, but you know you can't stop it, where does it leave you? The answer is that it leaves you with an obligation to be honest about where you are in history's great cycle, and what you have the power to do and what you don't (Kingsnorth, 2012).

Paul Kingsnorth quoted by Calvert (2017) has said, "simply by paying attention to the darker things in the world ... gives people permission to have a conversation". Kingsnorth is highly critical of sustainability as "an entirely human centered piece of politicking disguised as concern for the planet". The situation is far more dangerous that the smooth term 'sustainable' indicates. There is little foreseeable 'sustainability' for so many reefs facing widespread dying within a few of years. But "paying attention" has revelatory educational meaning in the Anthropocene/Dromosphere.

\section{Snorkeling forward}

Richard Kahn (2008, p. x) uses the metaphor of ocean in his attempt to understand our current predicament as educators and ecopedagogists: 
We move, then, in a sea of possibilities and swirling energies. Amidst these energies arises the great wave; and it is crashing and we who are threatened with annihilation and asked to threaten others with the same are its driftwood. Will we be smashed to splinters upon the polluted beach of no tomorrow? Will we surf the awesome tube of this grave peril and move laterally across it into newly imagined freedoms? Or will we head outward into deeper waters still, floating upon unfathomable depths, dangers and possibilities even as of yet unforeseen?

Bob Jickling (2013) notes that experiential epistemologies are underrepresented in environmental education practices. This Special Issue is a practical attempt to redress this in the formal, disciplined literature. Environmental education has a long history of contesting an educational status quo since its inception in the early 1970s. Drawing on Andy Stables' more recent remark that education is about doing the impossible, Jickling argues that education that can transcend the status quo, though this requires non-conformism and risk. He encourages us to take chances as, "some of the best education will take place on the edge, between present realities and future possibilities". The times demand that we will be "pushing the pedagogical and theoretical envelope". Oceanscaping/scoping and the ecopedagogy of snorkeling can be further pushed within formal and informal environmental education.

It is respectful to and to coral reefs to undertake the immersive offshore experiences and not leave the reefs as absent, non-presenced, unattended, un-witnessed, to be learnt about only in classrooms, viewed on the Internet, but not immersed in and not properly experienced and felt. So why not still go to out into the ocean to educationally experience coral reefs in the age of coral ecocide? Why not continue to put effort into further developing our understanding of oceanscape ecopedagogy? Calvert (2017) wrote something interesting when trying to tackle the implications of ecocide. He said, "beauty and justice are closer together than they first seem".

Here's something to know about beauty. The ancient Greeks had a wonderful definition for it: beauty meant, "to be of one's hour" (Ferguson, 2016). It is my view that it's always better to inhabit (and embody) our particular space and time, rather than run away from difficult reality in 'classroom' fear and in cognitive distress, This is what I have chosen to do, what my colleagues have chosen to do, and what our students who come with us offshore have chosen to do. Coral reefs are beautiful. Even with masses of dead corals, there are beautiful fish, beautiful new growths, and profoundly moving relational experiences to be had. As Ferguson (2016) writes, it is important to "cut through our regrets, our fears, and our distraction [and] find [the] exquisite chance to know what it's like to be truly alive". And snorkeling within a coral reef is truly a being-deeply-alive experience.

In answer to the ecopedagogical question, "Whereto from here?" my answer is, go to the seas, the oceans, the bays, inlets and islands, and immerse yourselves.

\section{References}

Australian Council of Learned Academies [ACOLA] (2017.The role of energy storage in Australia's future energy supply mix. Melbourne, Australia: ACOLA. Retrieved from http://acola.org.au/wp/esp/

Burchett, W.G. (1981). At the barricades. Melbourne, Australia: Macmillan.

Burk, D. (2011). A grey ecology is needed now more than ever. In A. Kroker \& M. Kroker (eds). Theory beyond the codes. Retrieved from http://www.ctheory.net/articles.aspx?id=681

Calvert, B. (2017). How to face the ecocide: Climate chaos, mass extinction, and the collapse of civilization. So what if we're doomed? High Country News. July 242017.

Chawla, L. (1998). Significant life experiences revisited. A review of research on sources of environmental sensitivity. Journal of Environmental Education. 29(3), 11-21. doi: 10.1080/00958969809599114 cummings, e.e. (1976) Complete poems 1904 - 1962. (G. J. Firmage, ed.). New York, NY: Liveright Publishing. Davies, B., \& Whitehouse, H. (1997). Men on the boundaries: Landscapes and seascapes. Journal of Gender Studies, 6 (3), 237-254. doi: 10.1080/09589236.1997.9960685

Dunkley, R. (2018.this issue)

Finkel, A., Moses, K., Munroe, C., Effeney, T., \& O'Kane, M. (2017). Independent Review into the Future Security of the National Electricity Market - Blueprint for the Future. Canberra: Commonwealth of Australia. Retrieved from https://www.energy.gov.au/publications/independent-review-future-security-national-electricity-marketblueprint-future

Foyster, G. (2016). My climate denial is worse that Malcolm Roberts'. Eureka Street, 26(19). 25 September 2016. Gough, A. (2017). Educating for the marine environment: Challenges for schools and scientists. Marine Pollution Bulletin, 124 (2), 633-638.

Griffiths, J. (2015) Savage grace: A journey into wildness. Berkeley, CA: Counterpoint.

Hannam, P. (2017a). Warming limit of 1.2 degrees needed to save Great Barrier Reef: Expert panel. Sydney Morning Herald. August 2, 2017.

Hannam, P. (2017b). Australia's carbon pollution soars, government data shows. Sydney Morning Herald. August 4, 2017.

Higgins, P. (2017a). Eradicating ecocide. Retrieved from http://eradicatingecocide.com/polly/

Higgins, P. (2017b). Why ecocide crimes are crimes of recklessness. February 17, 2017. Retrieved from http://eradicatingecocide.com/2017/02/27/why-ecocide-crimes-are-crimes-of-recklessness/

Hughes, et. al. (2017) Global warming and recurrent mass bleaching of corals. Nature, 543, 373-377. DOI $10.1038 /$ nature21707

Lamb, J. L., True, J. D., Piromvaragorn, S., \& Willis, B. L. (2014). Scuba diving damage and intensity of tourist activities increases coral disease prevalence. Biological Conservation, 178, 88-96. 
Reef 2050 Plan Independent Expert Panel (2017). Advice on responding to mass coral bleaching of the Great Barrier Reef: Outcomes from Workshop 5 May 2017. Retrieved from

https://www.environment.gov.au/system/files/pages/abff0d5e-b94d-4495-b79b-90dc52274f69/files/rac-adviceresponding-mass-coral-bleaching-gbr.pdf

Jickling. B. (2013). Normalizing catastrophe: An educational response. Environmental Education Research, 19 (2), 161-176. doi: 10.1080/13504622.2012.721114

Kahn, R. (2008). Towards ecopedagogy: Weaving a broad-based pedagogy of liberation for animals, nature and the oppressed people of the earth. The critical pedagogy reader ( $v 2$ ). Retrieved

from http://www.rabbitadvocacy.com/pdf_files/Nature\%20Liberation\%20Connection.pdf

Kingsnorth, P. (2012). Dark ecology. Orion Magazine. Retrieved from https://orionmagazine.org/article/darkecology/

Krien, A. (2017) The long goodbye: Coal, coral and Australia's climate deadlock. Quarterly Essay. Issue 66, 2017.

Kunnie, J. E. (2015). The cost of globalization. Dangers to the Earth and its people. Jefferson, NC: McFarland.

Mahy, M. (1973/1985/1996). The man whose mother was a pirate. London, England: Puffin Books

Nakagawa, Y. (2018, this issue)

Orphan, K. (2014). Bearing witness. Retrieved from https://kennorphan.com/2014/10/11/bearing-witness-2/

Payne, P. (2018, this issue). Introduction. The framing of ecopedagogy as/in scapes: Methodology of the issue. The Journal of Environmental Education, 49(2)

Payne, P. (2017). An ecophenomenology of children's experience in the Anthropocene: Theory building and research development. In M. Fleer \& B. van Oers (Eds.) International Handbook on Early Childhood Education (pp. 117-162). Dordecht: Springer.

Payne, P. (2014). Vagabonding slowly. Ecopedagogy, metaphors, figurations and nomadic ethics. Canadian Journal of Environmental Education, 19, pp. 47-69.

Rodrigues, C. (2018, this issue).

Rousselle, D. (2012). Postmodern pollution. In A. Kroker \& M. Kroker (Eds.). Theory beyond the codes. Retrieved from http://www.ctheory.net/articles.aspx?id=707

Stedman, R.C. (2016). Subjectivity and social-ecological systems: A rigidity trap (and sense of place as a way out). Sustainability Science, 11, 891-901. doi: 10.1007/s11625-016-0388-y

Stepath, C.M., \& Whitehouse, H. (2008). Ripple effects: A study of the learning outcomes of taking university students to a local coral reef. In W. J. Filho \& D. Carpenter (Eds.) Sustainability in the Australasian_University Context (pp. 129-139). Frankfurt, Germany: Peter Lang.

Stepath, C.M. (2015). Coral reefs: Australian sites for learning environmental education. Saarbrücken, Germany: Lambert Publishing

Tidal Tao (2017). What is snorkeling? Retrieved from http://www.tidaltao.com/what-is-snorkeling

Wallace-Wells, D. (2017) The uninhabitable Earth. New York Magazine. July 9 2017. Retrieved

from http://nymag.com/daily/intelligencer/2017/07/climate-change-earth-too-hot-for-humans.html

Wijdekop, F. (2016). Against ecocide: Legal protection for the Earth. Great transition initiative: Towards a

transformative vision and praxis. August 2016. Retrieved from http://www.greattransition.org/publication/againstecocide

Virilio, P. (2010). Grey ecology. New York, NY: Atrophos Press.

Whitehouse, H. (2000). Talking Up Country, PhD Thesis, Townsville, Australia: James Cook University.

Whitehouse, H. (2011). Talking up Country: Language, natureculture and interculture in Australian environmental education research. Australian Journal of Environmental Education, 27(1), 56-67. doi: $10.1017 / \mathrm{S} 0814062600000070$

Whitehouse, H., Watkin Lui, F., Sellwood, J., Barrett, M. J., \& Chigeza, P. (2014). Sea Country: navigating Indigenous and colonial ontologies in Australian environmental education. Environmental Education Research, 20 (1). 56-69. doi: 10.1080/13504622.2013.852655

Whitehouse, H., Taylor, M., Evans, N., Doyle, T., Sellwood, J., \& Zee, R. (in press). A sea country learning partnership in times of Anthropocenic risk: Offshore coral reef education and our story of practice. Australian Journal of Environmental Education. 